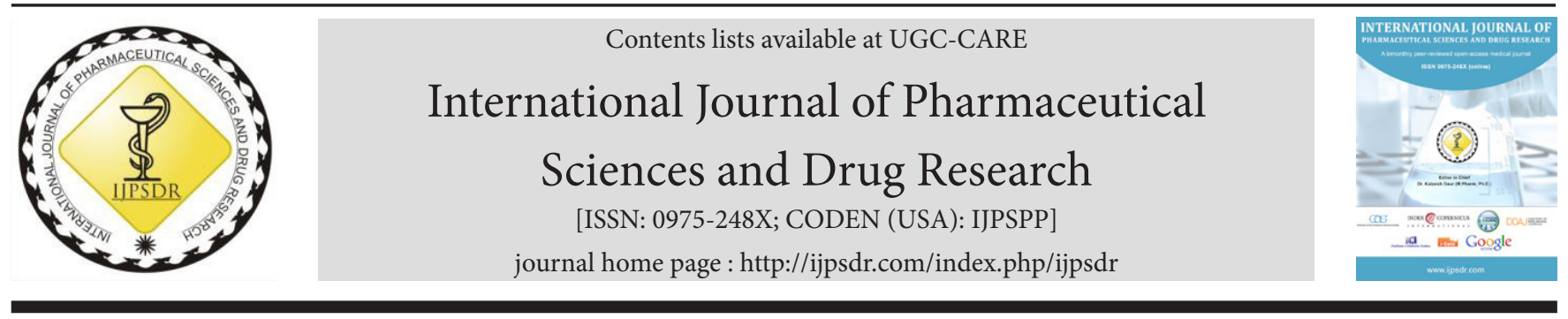

Research Article

\title{
Synthesis and Biological Evaluation of Thiosemicarbazone Analogues of Ornidazole as Antifungal Agents
}

\author{
N. Kumar ${ }^{1}$, T. Aggarwal ${ }^{2}$, G. Singh ${ }^{2}$, P. Kumar ${ }^{2}$, R. Kumar ${ }^{2,3}$, C. Kaur ${ }^{3 *}$ \\ ${ }^{1}$ Ind-Swift Laboratories Limited, Bhagwanpur, Behra-140507, Punjab, India \\ ${ }^{2}$ Lovely School of Pharmaceutical Sciences, Lovely Professional University, Phagwara-144401, Punjab, India \\ ${ }^{3}$ Department of Pharmaceutical Chemistry, Khalsa College of Pharmacy, Amritsar-143001, Punjab, India
}

\begin{tabular}{l} 
A R T I C L E I N F O \\
\hline Article history: \\
Received: 06 December, 2019 \\
Revised: 21 January, 2020 \\
Accepted: 23 January, 2020 \\
Published: 30 January, 2020 \\
Keywords: \\
Antifungal, Aspergillus niger, \\
Ornidazole, Thiosemicarbazone. \\
D0I: \\
10.25004/IJPSDR.2020.120112
\end{tabular}

\section{INTRODUCTION}

A 5-Nitroimidazoles are well-established heterocyclic moieties for their anti-protozoal and antibacterial potential. ${ }^{[1]}$ Numerous nitroimidazole derivatives are used clinically as potent antiprotozoal drugs as well as antifungal agents such as metronidazole, nimorazole, and ornidazole. ${ }^{[2]}$ The pharmacological potential depends upon the position of the nitro group as 5-nitro compounds are more active than 4 -nitro derivatives. ${ }^{[3,4]}$

The effectiveness of these compounds is due to its electron acceptance tendency in the endogenous reduction reaction. Since it has redox potential lower than the protein ferrodoxin, which is found in an anaerobic organism, its nitro group is reduced. This reduced form then causes interference in carbohydrate metabolism and nucleic acid synthesis. ${ }^{[2]}$
Nitroimidazoles have a wide spectrum of activity along with numerous side effects like hepatotoxicity, skin rashes, gastrointestinal disorder, vomiting, nausea etc. Thus an attempt has been made to synthesis a new bioactive series of 5-nitroimidazole derivatives.

Ornidazole[1-(2-hydroxy-3-chloroproryl)-2-methyl5-nitroimidazole] (1) is a synthetic derivative of 5-nitroimidazole which possesses anti-protozoan, ${ }^{[5]}$ antimycotic ${ }^{[6]}$ and antibacterial potential ${ }^{[2,7]}$ due to inhibition of microbial DNA synthesis and degradation of existing DNA through generation of more reactive amine group from the nitro group. ${ }^{[8-11]}$

In 1966, Hoffman-La-Roche synthesized the drug. ${ }^{[9,11]}$ It has similarity to metronidazole in terms of molecular structure and pharmacological action, ${ }^{[1]}$ but certain therapeutic advantages over metronidazole which results in dosage frequency reduction as well as duration

\footnotetext{
*Corresponding Author: Ms. Charanjit Kaur

Address: Sh. Inder Kumar Gujral, Punjab Technical University, Kapurthala-144603, Punjab, India

Email $\square$ : charanjitkaur13@gmail.com

Relevant conflicts of interest/financial disclosures: The authors declare that the research was conducted in the absence of any commercial or financial relationships that could be construed as a potential conflict of interest.

Copyright (C) $2020 \mathrm{~N}$ Kumar et al. This is an open access article distributed under the terms of the Creative Commons Attribution- NonCommercialShareAlike 4.0 International License which allows others to remix, tweak, and build upon the work non-commercially, as long as the author is credited and the new creations are licensed under the identical terms.
} 
of treatment (longer half-life-12-14 hours and 6-8 hours, respectively) in most clinical infections and this becomes the reason to select it for further research and modifications to enhance its therapeutic effect. ${ }^{[1]}$

Ornidazole releases chlorinated side chain during metabolism in male animals and exerts antifertility action reversibly ${ }^{[6]}$ through conversion into 3-chlorolactaldehyde which possess the capacity to inhibit the ATP synthesis in sperm through inhibition of the glycolytic enzyme (3-GPD) glyceraldehydes-3-phosphate dehydrogenase. ${ }^{[8]}$

Thiosemicarbazones (2) have been known for their antiviral, anticancer, and parasiticidal action. ${ }^{[12,13]}$ The effectiveness of thiosemicarbazone analogs has been reported due to its action against cysteine proteinases. ${ }^{[12]}$ In addition, numerous thiosemicarbazone derivatives possess antifungal ${ }^{[14]}$ antioxidant, antiproliferative, and many other biological properties. ${ }^{[12,15]}$ By changing the chemical substituent at the 1 and 2-positions of the 5-nitroimidazole, it is possible to synthesize molecules that are active against a broader range of microorganisms. ${ }^{[16-18]}$ Demirayaketal., (1999) synthesized some 1-[2-(substituted pyrrol-1-yl)ethyl]-2-methyl-5-nitroimidazole derivatives and check the antibacterial and antifungal activity. As compared to metronidazole (i.e. $>1024 \mathrm{mg} / \mathrm{ml}$ ), the compounds 3a-d showed highest activity (MIC against S. aureus (i.e. $8 \mathrm{mg} / \mathrm{mL}$ ) and entirely found ineffective for antifungal activity. ${ }^{[19]}$

Benkli et al., (2003) carried out synthesis of some 3-[2-(2-Methyl-5-nitroimidazol-1-yl) ethyl]-5-arylidenethiazolidine-2,4-diones (5) and evaluated antifungal and antibacterial activity. All the synthesized were found moderately active ( MIC $=62.5 \mu \mathrm{g} / \mathrm{mL}$ ) against staphylococcus in comparison to fluconazole. ${ }^{[20]}$ Frank et al, (2005) synthesized a series of 1,3,4-oxadiazoles derivatives of imidazole (6) and tested their antifungal and antibacterial potential. Most of the derivatives showed most promising antifungal and antibacterial action (MIC $=0.25 \mu \mathrm{g} / \mathrm{mL}$ ) when compared with fluconazole. ${ }^{[21]}$ Frank et al, (2007) carried out the microwave-assisted synthesis of 5-substituted-2-(2-methyl-4-nitro-1-imidazomethyl)1,3,4-oxazoles (7) with nitroimidazole nucleus and their anti-inflammatory, antifungal, and antibacterial activity. Compounds (7a-d) show good antifungal activity. The zone of inhibition $(\mathrm{mm})$ was found to be $12-14 \mathrm{~mm}$ for Trichophyton at $10 \mathrm{mg} / \mathrm{mL}$ concentration as compared with standard Ciclopiroxolamine $(20 \mathrm{~mm}){ }^{[22]}$ Olender et al., (2009) synthesized nitroimidazole derivatives by reacting epichlorohydrin, epoxypropane, or phenacyl bromide with 4,5-dinitro and 2-methyl-4,5-nitroimidazoles in alkylation reactions. ${ }^{[3]} 4$-Aminoimidazole derivatives were also synthesized and compounds were analyzed as anti-fungal and antioxidant. ${ }^{[23,24]}$ Amongst those, compounds (8a-b) exhibited very significant fungistatic activity $\left(\mathrm{ED}_{50}<25\right)$ against Sclerophoma pityophila. ${ }^{[3]}$ Kumar et al, (2010) also synthesized imidazole derivatives and compound 2-(2-methyl-5-nitro-1H-imidazol-1-yl) ethyl dimethylcarbamodithioate (9) showed remarkable anti-trichomonas $(\mathrm{MIC}=1.14 \pm 0.20 \mu \mathrm{M}$ ) along with mild antifungal action. ${ }^{[25]}$ All the reported derivatives of nitroimidazole with antifungal activity have been illustrated in Fig. 1.

A survey of chemical literature revealed that ornidazole and thiosemicarbazones have antifungal activity and ornidazole (Fig. 2) analogs have not been reported at position 2 .
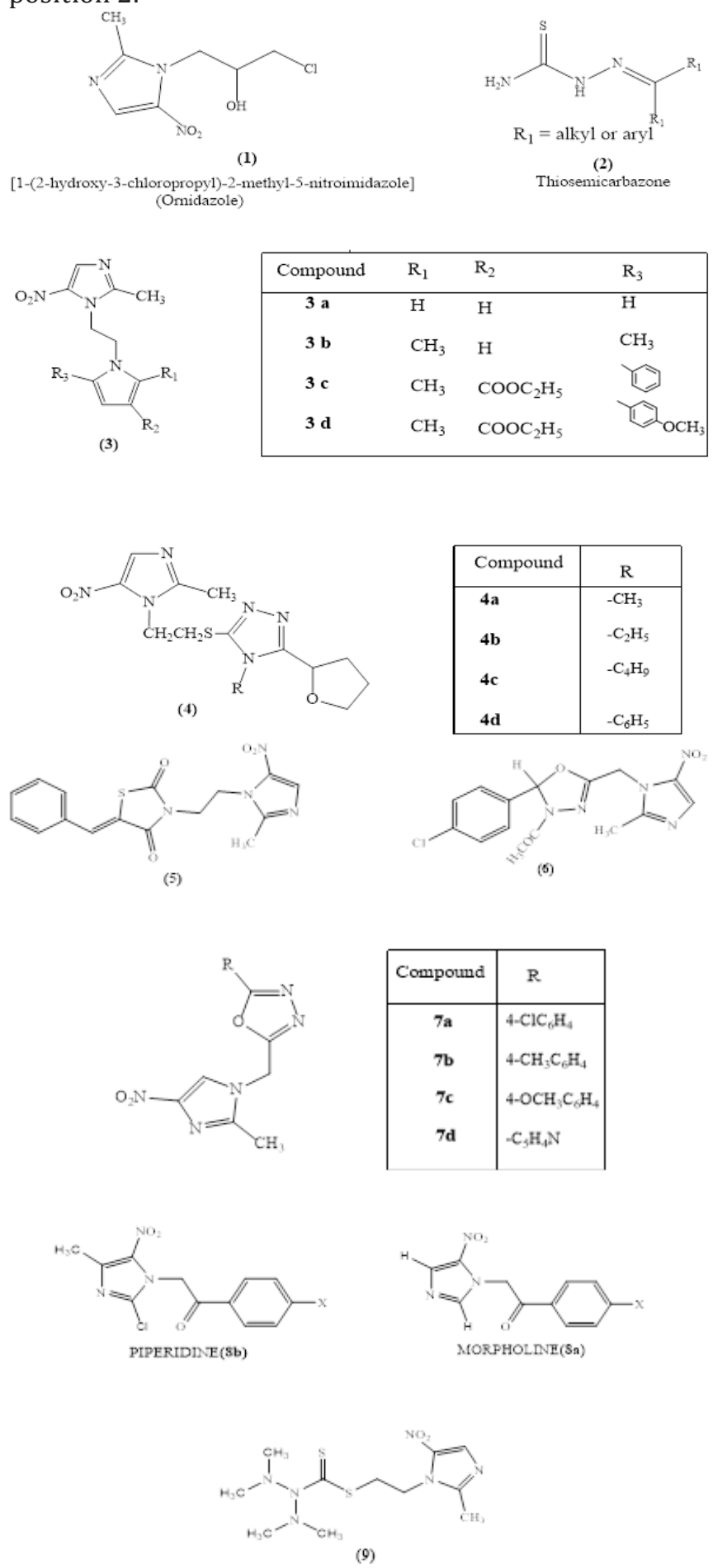

Fig. 1: Representative structure of derivatives of nitroimidazole with antifungal activity 


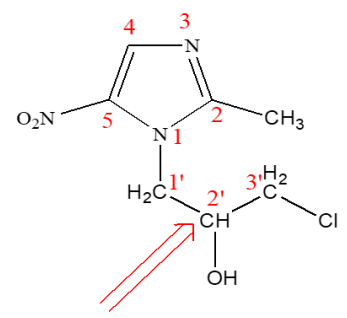

Fig. 2: Ornidazole moiety

From a literature survey, it has been concluded that 5-nitroimidazole with thiosemicarbazone results in a compound with potent antifungal activity. So we decided to synthesize ornidazole thiosemicarbazone analogs at position 2/ of ornidazole.

\section{Materials AND METhods}

\section{Chemicals and Instruments}

The chemical used in our experimental work was procured from Loba Chemie Pvt. Ltd., Mumbai, India, and Qualikems Fine Chem Pvt. Ltd. Vadodara, India.

The melting point was determined using an open capillary method and were uncorrected. Fourier-transform infrared spectroscopy (FTIR) spectra were recorded using Shimadzu 8400 Co. Ltd., Singapore, and the samples were analyzed using potassium bromide ( $\mathrm{KBr}$ ) pellets. ${ }^{1} \mathrm{H}-\mathrm{NMR}$ spectra were collected on Bruker Avance II 400 NMR spectrometer. Thin layer chromatography (TLC) analysis was done to check the purity of the compounds on precoated aluminum plates (Silica gel $60 \mathrm{~F}_{254}$ Merck-Germany).

\section{Synthetic Procedures (Fig. 3)}

- For the preparation of 1-(3-chloro-propan-2-one)-2methyl-5-nitroimidazole(C-1)

To a stirred solution of ornidazole $(0.0045 \mathrm{~mol}, 1 \mathrm{gm})$ in 10 $\mathrm{N} \mathrm{H}_{2} \mathrm{SO}_{4}(5 \mathrm{~mL})$ a warm solution of $\mathrm{Na}_{2} \mathrm{Cr}_{2} \mathrm{O}_{7} \cdot 2 \mathrm{H}_{2} \mathrm{O}(0.0046$ mol, $1.41 \mathrm{gm}$ ) in $4.1 \mathrm{~mL}$ of $\mathrm{H}_{2} \mathrm{O}$ was added dropwise with stirring over 30 minutes at room temperature. The mixture was allowed to stir overnight. Reaction completion was monitored by TLC and extracted with ethyl acetate. The crude product was dried and recrystallized from ethanol to give compound.

- For the preparation of 1-[(3-Chloropropyl)-2-methyl5 -nitroimidazole]thiosemicarbazone (C-2) 1-(3-chloro-propan-2-one)-2-methyl-5-nitroimidazole (C-1) $(0.29 \mathrm{gm}, 0.001 \mathrm{~mol})$ and thiosemicarbazide ( $0.182 \mathrm{gm}, 0.002 \mathrm{~mol}$ ) in ethanol $(50 \mathrm{~mL}$ ) by adding $\mathrm{HCl}$ to acidic medium was refluxed overnight and the reaction was monitored by TLC after refluxing the mixture was cooled over ice-bath. The crude product was recrystallized from ethanol and water to give compound.

- For the preparation of Methyl phenyl carbamodithioate (MPC)

To a solution of aniline (1.9 gm, $0.02 \mathrm{~mol})$ in DMSO $(20 \mathrm{~mL})$, carbon disulfide (1.5 gm, $0.02 \mathrm{~mol})$, and $20 \mathrm{M}$ aqueous $\mathrm{NaOH}$ solution $(1.2 \mathrm{~mL})$ were added dropwise over 30 minutes with stirring at $5-10^{\circ} \mathrm{C}$. The stirring was continued for 5 hrs. Reaction completion was monitored by TLC. Then, dimethyl sulfate $(2.5 \mathrm{gm}, 0.02 \mathrm{~mol})$ was added dropwise with stirring at $0-5^{\circ} \mathrm{C}$ and stirring was continued for another 3 hours. After 3 hours, the reaction mixture was poured into ice-water. The product was filtered, dried in a vacuum desiccator, and recrystallized from benzene to give compound MPC.

- For the preparation of 4-Phenyl thiosemicarbazide (PT)

Methyl phenyl carbamodithioate (MPC) (1.5 gm, $0.01 \mathrm{~mol}$ ) was dissolved in absolute ethanol $(50 \mathrm{ml})$ and hydrazine hydrate $(0.5 \mathrm{gm}, 0.01 \mathrm{~mol})$ was added dropwise with stirring at $5-10^{\circ} \mathrm{C}$. Stirring was further continued for 5 hours at $50^{\circ} \mathrm{C}$, and then the reaction mixture was poured into ice-water. The solid obtained was filtered, dried, and recrystallization was done using ethanol.

- For the preparation of 1-[(3-chloropropyl)-2-methyl-5nitroimidazole]-4-phenyl-3-thiosemicarbazone (C-3) 1-(3-chloro-propan-2-one)-2-methyl-5-nitroimidazole (C-1) ( $0.65 \mathrm{gm}, 0.003 \mathrm{~mol})$ and 4-phenyl thiosemicarbazide $(1.003 \mathrm{gm}, 0.006 \mathrm{~mol})$ in ethanol $(50 \mathrm{~mL})$ by adding $\mathrm{HCl}$ to acidic medium was refluxed overnight and the mixture was cooled over ice-bath. The crude product obtained was recrystallized from ether.

- For the preparation of methyl (3-methylphenyl) carbamodithioate (MMPC)

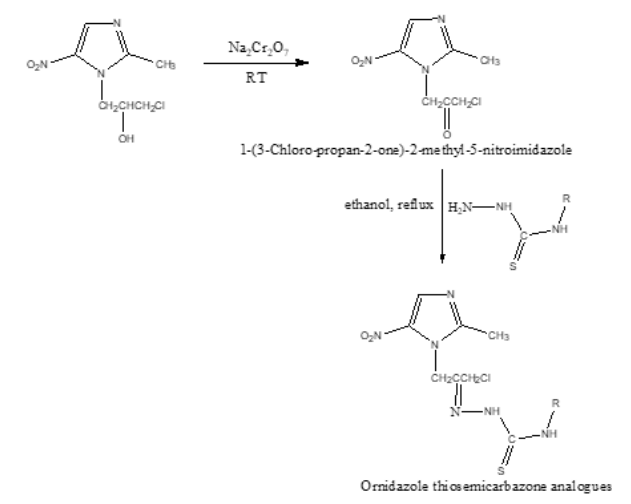

Schem e: 1 Synthesis of ornidazole thiosemicarbazone analogues

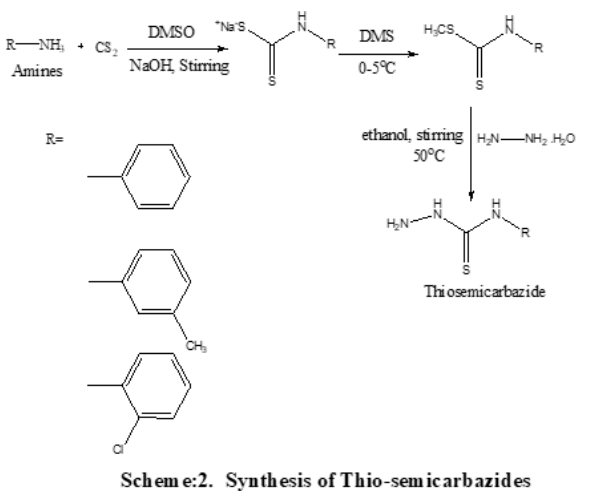

Fig. 3: Synthetic schemes for the synthesis of derivatives of ornidazole. 
To a solution of m-toluidine $(2.1 \mathrm{gm}, 0.02 \mathrm{~mol})$ in DMSO $(20 \mathrm{~mL})$, carbon disulfide (1.52 gm, $0.02 \mathrm{~mol})$, and 20 Molar aqueous $\mathrm{NaOH}$ solution $(1.2 \mathrm{~mL})$ were added dropwise simultaneously over 30 minutes with stirring at $5-10^{\circ} \mathrm{C}$. The mixture was further allowed to stir for 5 hours. TLC monitored reaction completion. To the reaction mixture, dimethyl sulfate ( $2.5 \mathrm{gm}, 0.02 \mathrm{~mol}$ ) was added dropwise with stirring at $0-5^{\circ} \mathrm{C}$ and stirring was continued for another 3 hours. After 3 hours, the reaction mixture was poured into ice-water. The solid obtained was filtered, dried in vacuum desiccator, and recrystallized from ethanol to give compound.

- For the preparation of 4-(3-Methylphenyl)thiosemicarbazide (MPT)

Methyl (3-methylphenyl) carbamodithioate $(1.5 \mathrm{gm}$, $0.01 \mathrm{~mol}$ ) was dissolved in absolute ethanol $(50 \mathrm{~mL})$ and hydrazine hydrate $(0.5 \mathrm{gm}, 0.01 \mathrm{~mol})$ was added dropwise with stirring while maintaining the temperature at $5-10^{\circ} \mathrm{C}$. Stirring was further continued for 5 hours at $50^{\circ} \mathrm{C}$ and then the reaction mixture was poured into ice-water. The solid obtained was filtered, dried, and recrystallized from ethanol to give compound.

- For the preparation of 1-[(3-chloropropyl)-2-methyl5-nitroimidazole]-4-(3-methylphenyl) thiosemicarbazone (C-4)

1-(3-chloro-propan-2-one)-2-methyl-5-nitroimidazole (C-1) $(0.65 \mathrm{gm}, 0.003 \mathrm{~mol})$ and 4-(3-MethylPhenyl) thiosemicarbazide $(1.08 \mathrm{gm}, 0.006 \mathrm{~mol})$ in ethanol $(50 \mathrm{~mL})$ by adding $\mathrm{HCl}$ to acidic medium was refluxed overnight and after refluxing the mixture was cooled over ice-bath. The crude obtained was recrystallized from ethanol to give compound.

- For the preparation of Methyl-(2-chlorophenyl) carbamodithioate (MCC):

To a solution of chloroaniline ( $2.55 \mathrm{gm}, 0.02 \mathrm{~mol}$ ) in DMSO (20 mL), carbon disulfide ( $1.5 \mathrm{gm}, 0.02 \mathrm{~mol}$ ) and 20 Molar aqueous $\mathrm{NaOH}$ solution $(1.2 \mathrm{~mL})$ were added dropwise simultaneously over 30 minutes with stirring at $5-10^{\circ} \mathrm{C}$. The mixture was further allowed to stir for $5 \mathrm{hrs}$. To the reaction mixture, dimethyl sulfate $(2.5 \mathrm{gm}, 0.02 \mathrm{~mol})$ was added dropwise with stirring at $0-5^{\circ} \mathrm{C}$ and stirring was continued for another 3 hours. After 3 hours, the reaction mixture was poured into ice-water. The solid obtained was filtered, dried in a vacuum desiccator, and recrystallized from benzene to give compound.

- For the preparation of 4-(2-Chlorophenyl) thiosemicarbazide (CIPT)

Methyl-(2-chlorophenyl) carbamodithioate (2.1gm, $0.01 \mathrm{~mol}$ ) was dissolved in absolute ethanol $(50 \mathrm{~mL})$ and hydrazine hydrate $(0.5 \mathrm{gm}, 0.01 \mathrm{~mol})$ was added dropwise with stirring by keeping the reaction mixture at $5-10^{\circ} \mathrm{C}$. Stirring was further continued for 5 hours at $50^{\circ} \mathrm{C}$, and then the reaction mixture was poured into ice-water. The solid obtained was filtered, dried, and recrystallized from ethanol to give compound.
- For the preparation of 1-[(3-Chloropropyl)-2-methyl-5nitroimidazole]-4-(2-chlorophenyl) thiosemicarbazone (C-5)

1-(3-chloro-propan-2-one)-2-methyl-5-nitroimidazole (C-1) $(0.65 \mathrm{gm}, 0.003 \mathrm{~mol})$ and 4 -(2-chloro) phenyl thiosemicarbazide $(1.2 \mathrm{gm}, 0.006 \mathrm{~mol})$ in ethanol $(50 \mathrm{~mL})$ by adding $\mathrm{HCl}$ to acidic medium was refluxed overnight and after refluxing the mixture was cooled over ice-bath. The crude obtained was recrystallized from ethanol to give compound.

Characterisation (Fig.4) includes structure of all synthesized compounds:

\section{1-(3-Chloro-propan-2-one)-2-methyl-}

5-nitroimidazole (C-1)

Chemical formula: $\mathrm{C}_{7} \mathrm{H}_{8} \mathrm{ClN}_{3} \mathrm{O}_{3}$; molecular mass: 217; elemental fnalysis: $\mathrm{C}, 38.64 ; \mathrm{H}, 3.71 ; \mathrm{Cl}, 16.29 ; \mathrm{N}, 19.31$; O, 22.06; Yield 30\%; Rf value: 0.36; M.P: $109-111^{\circ} \mathrm{C}$; 1H NMR (400MHz, DMSO): $\delta=8.01(1 \mathrm{H}, \mathrm{s}), 5.42(2 \mathrm{H}, \mathrm{s})$, 4.58(2H, s), 2.36(3H, s); IR (KBr, cm-1): 2929, 1751, 1637, 1560, 1373, 1273, 1143, 1193, 837, 740; MS m/z: 217.32 $\left(\mathrm{MH}^{+}\right)$.

\section{1-[(3-Chloropropyl)-2-methyl-5-nitroimidazole] thiosemicarbazone ( $\mathrm{C}-2)$}

Chemical formula: $\mathrm{C}_{8} \mathrm{H}_{11} \mathrm{ClN}_{6} \mathrm{O}_{2} \mathrm{~S}$; molecular mass:290; element alanalysis: $\mathrm{C}, 33.05 ; \mathrm{H}, 3.81 ; \mathrm{Cl}, 12.19 ; \mathrm{N}, 28.91 ; \mathrm{O}$, 11.01; S, 11.03; Yield30\%; Rf value: 0.7; M.P: $120-130^{\circ} \mathrm{C}$; $1 \mathrm{H}$ NMR $(400 \mathrm{MHz}, \mathrm{DMSO}): \delta=9.65(1 \mathrm{H}, \mathrm{s}) ; 7.94(1 \mathrm{H}, \mathrm{s})$; $3.89(2 \mathrm{H}, \mathrm{s}) ; 3.73(2 \mathrm{H}, \mathrm{s}) ; 1.97(2 \mathrm{H}, \mathrm{s}) ; 1.95(3 \mathrm{H}, \mathrm{s}) ; \mathrm{IR}(\mathrm{KBr}$, cm-1): 3371, 3261, 3176, 1645, 1622, 1527, 1373, 804, 705; MS m/z: $290.04\left(\mathrm{MH}^{+}\right)$.

\section{Methylphenylcarbamodithioate (MPC)}

Chemical formula: $\mathrm{C}_{8} \mathrm{H}_{9} \mathrm{NS}_{2}$; molecular mass: 183 ; elemental analysis: C, 52.42; H, 4.95; N, 7.64; S, 34.99; Yield 40\%; Rf value: 0.7; M.P: $92-93^{\circ} \mathrm{C}$; $1 \mathrm{H}$ NMR $(400 \mathrm{MHz}$, DMSO): $\delta=7.48-7.23(5 \mathrm{H}, \mathrm{m}) ; 4(1 \mathrm{H}, \mathrm{s}) ; 2.07(3 \mathrm{H}, \mathrm{s})$; IR ( $\mathrm{KBr}$, cm-1): 3149, 2949, 1510, 1247, 1141, 810, 704.MS m/z: $183.04\left(\mathrm{MH}^{+}\right)$.

\section{4-Phenylthiosemicarbazide (PT)}

Chemical Formula: $\mathrm{C}_{7} \mathrm{H}_{9} \mathrm{~N}_{3} \mathrm{~S}$; molecular mass: 167; elemental Analysis: C, 50.27; H, 5.42; N, 25.13; S, 19.17; Yield 68.96\%; Rf value: 0.5 ; M.P: $130-132^{\circ} \mathrm{C}$; $1 \mathrm{H}$ NMR (400MHz, DMSO): $\delta=6.8-7.7(5 \mathrm{H}, \mathrm{m}) ; 4(1 \mathrm{H}, \mathrm{s}) ; 2(3 \mathrm{H}, \mathrm{s})$; IR (KBr, cm-1): 3304, 3167, 2970, 1529, 1494, 1286, 1068; MS m/z: $167.04\left(\mathrm{MH}^{+}\right)$.

\section{1-[(3-Chloropropyl)-2-methyl-5-nitroimidazole]-4-phenyl- 3-thiosemicarbazone ( $C$-3)}

Chemical formula: $\mathrm{C}_{14} \mathrm{H}_{15} \mathrm{ClN}_{6} \mathrm{O}_{2} \mathrm{~S}$; molecular mass:366; elemental snalysis: $\mathrm{C}, 45.84 ; \mathrm{H}, 4.12 ; \mathrm{Cl}, 9.66 ; \mathrm{N}, 22.91$; $0,8.72$; S, 8.74; Yield30\%; Rf value: 0.92; M.P:210$213{ }^{\circ} \mathrm{C}$; $1 \mathrm{H}$ NMR (400MHz, DMSO): $\delta=10.56(1 \mathrm{H}, \mathrm{s}) ; 8.07$ $(1 \mathrm{H}, \mathrm{s}) ; 7.48-7.23(5 \mathrm{H}, \mathrm{m}) ; 4.07(1 \mathrm{H}, \mathrm{s}) ; 3.54(2 \mathrm{H}, \mathrm{s}) ; 3.32(2 \mathrm{H}$, 
Synthesis and Biological Evaluation of Thiosemicarbazone Analogues of Ornidazole as Antifungal Agents

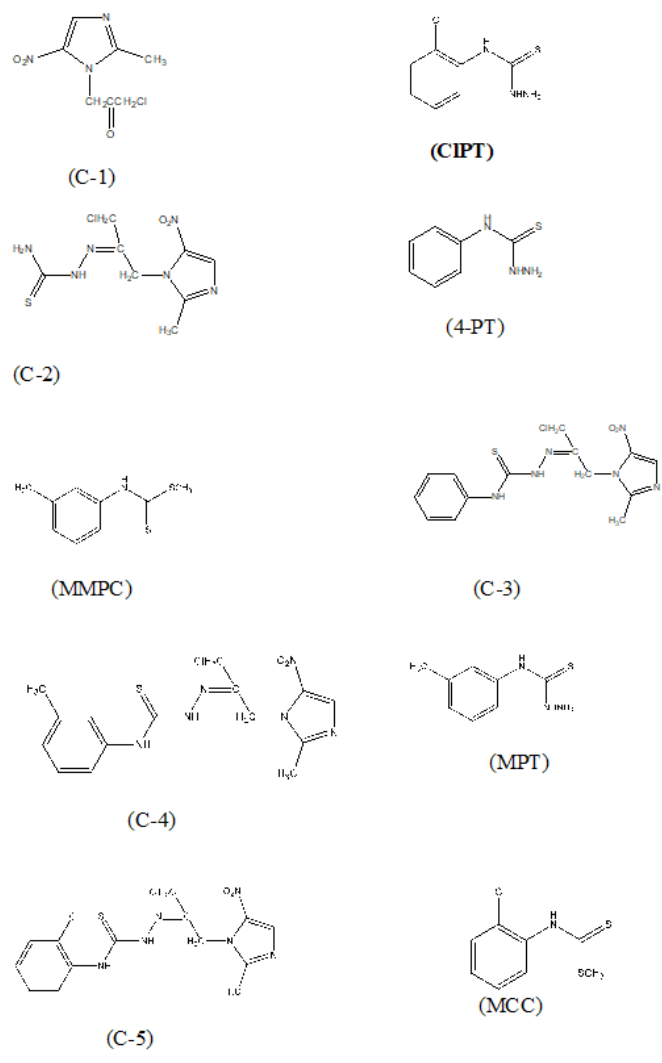

Fig. 4: Structures of synthesized compounds

s); $2.07(3 \mathrm{H}, \mathrm{s}) ; \mathrm{IR}(\mathrm{KBr}, \mathrm{cm}-1): 3302,2972,1641,1529,1498$, 1446, 1286, 1068, 896, 736.MS m/z: $366.07\left(\mathrm{MH}^{+}\right)$

Methyl-(3-methylphenyl)carbamodithioate (MMPC)

Chemical formula: $\mathrm{C}_{9} \mathrm{H}_{11} \mathrm{NS}_{2}$; molecular mass: 197.32; elemental analysis: $\mathrm{C}, 54.78 ; \mathrm{H}, 5.62 ; \mathrm{N}, 7.10 ; \mathrm{S}, 32.50$; Yield $60 \%$; Rf value: 0.6 ; M.P:78-80 ${ }^{\circ} \mathrm{C}$; $1 \mathrm{H}$ NMR (400MHz, DMSO): $\delta=7.08-6.59(4 \mathrm{H}, \mathrm{m}) ; 4(1 \mathrm{H}, \mathrm{s}) ; 2.55(3 \mathrm{H}, \mathrm{s}) ; 2.34(3 \mathrm{H}, \mathrm{s}) ; \mathrm{IR}$ (KBr, cm-1): 3122, 2918, 1637, 1558, 1496, 1313, 1035, 956,792, 692, 605; MS m/z: $197\left(\mathrm{MH}^{+}\right)$

\section{4-(3-MethylPhenyl)thiosemicarbazide (MPT)}

Chemical formula: $\mathrm{C}_{8} \mathrm{H}_{11} \mathrm{~N}_{3} \mathrm{~S}$; molecular mass: 181.26; elemental analysis: $\mathrm{C}, 53.01 ; \mathrm{H}, 6.12 ; \mathrm{N}, 23.18 ; \mathrm{S}, 17.69$ Yield 69.89\%; Rf value: 0.5; M.P:88-90 ${ }^{\circ} \mathrm{C}$; $1 \mathrm{H}$ NMR $(400 \mathrm{MHz}$, DMSO): $\delta=6.8-7.7(4 \mathrm{H}, \mathrm{m}) ; 4(1 \mathrm{H}, \mathrm{s}) ; 2.34(3 \mathrm{H}, \mathrm{s}) ; 2(3 \mathrm{H}, \mathrm{s})$; IR (KBr, cm-1): 3309, 3234, 2916, 1610, 1543, 1492, 1311, 1068, 777, 731; MS m/z: $181\left(\mathrm{MH}^{+}\right)$.

\section{1-[(3-Chloropropyl)-2-methyl-5-nitroimidazole]- 4-(3-methylphenyl) thiosemicarbazone (C-4)}

Chemical Formula: $\mathrm{C}_{15} \mathrm{H}_{17} \mathrm{ClN}_{6} \mathrm{O}_{2} \mathrm{~S}$; molecular mass: 380.85 ; elemental Analysis: C, 47.30; H, 4.50; Cl, 9.31; N, 22.07; O, 8.40; S, 8.42; Yield 46\%; Rf value: 0.85 ; M.P: $40-41^{\circ} \mathrm{C} ; 1 \mathrm{H}$ NMR (400MHz, DMSO): $\delta=10.04(1 \mathrm{H}, \mathrm{s}) ; 8.11(1 \mathrm{H}, \mathrm{s}) ; 8.01-$ 7.99(1H, d); 7.38-7.31(1H, t); 7.17-7.13(1H, d); 6.87(1H,s); 5.35(1H, s); 3.87(2H, s); 3.56(2H, s); 2.43(3H, s); $2.34(3 \mathrm{H}, \mathrm{s})$; IR (KBr, cm-1): 3302, 2918, 1666, 1531, 1492, 1373, 1193, 827, 781, 690; MS m/z: $380\left(\mathrm{MH}^{+}\right)$.
Methyl-(2-chlorophenyl)carbamodithioate (MCC)

Chemical formula: $\mathrm{C}_{8} \mathrm{H}_{8} \mathrm{ClNS}_{2}$; molecular mass: 217.74; elemental analysis: $\mathrm{C}, 44.13 ; \mathrm{H}, 3.70 ; \mathrm{Cl}, 16.28 ; \mathrm{N}, 6.43$; S, 29.45 Yield $70 \%$; Rf value: 0.8 ; M.P: $72-73^{\circ} \mathrm{C}$; $1 \mathrm{H}$ NMR (400MHz, DMSO): $\delta=7.4-6.75(4 \mathrm{H}, \mathrm{m}) ; 4(1 \mathrm{H}, \mathrm{s}) ; 2.55(3 \mathrm{H}, \mathrm{s})$; IR (KBr, cm-1): 3115, 2922, 1573, 1506, 1467, 1323, 1037, 868, 761; MS m/z: $217\left(\mathrm{MH}^{+}\right)$.

\section{4-(2-Chlorophenyl)thiosemicarbazide (CIPT)}

Chemical formula: $\mathrm{C}_{7} \mathrm{H}_{8} \mathrm{ClN}_{3} \mathrm{~S}$; molecular mass: 201.68; elemental analysis: $\mathrm{C}, 41.69 ; \mathrm{H}, 4.00 ; \mathrm{Cl}, 17.58 ; \mathrm{N}, 20.84$; S, 15.90 Yield $69.89 \%$; Rf value: 0.4 ; M.P: $109^{\circ} \mathrm{C} ; 1 \mathrm{H}$ NMR (400MHz, DMSO): $\delta=7.4-6.75(4 \mathrm{H}, \mathrm{m}) ; 4(1 \mathrm{H}, \mathrm{s}) ; 2(3 \mathrm{H}, \mathrm{s})$; IR (KBr, cm-1): 3311, 3279, 1612, 1550, 1523, 1440, 1290, 1074, 908, 744; MS m/z: $201\left(\mathrm{MH}^{+}\right)$.

1-[(3-Chloropropyl)-2-methyl-5-nitroimidazole]4-(2-chlorophenyl)thiosemicarbazone (C-5)

Chemical Formula: $\mathrm{C}_{14} \mathrm{H}_{14} \mathrm{Cl}_{2} \mathrm{~N}_{6} \mathrm{O}_{2} \mathrm{~S}$; molecular mass: 401.27; elemental Analysis: C, 41.90; H, 3.52; Cl, 17.67; N, 20.94; 0, 7.97; S, 7.99; Yield 46\%; Rf value: 0.85; M.P: $40-41^{\circ} \mathrm{C}$; $1 \mathrm{H} \mathrm{NMR}(400 \mathrm{MHz}, \mathrm{DMSO}): \delta=10.19(1 \mathrm{H}, \mathrm{s})$; 7.97(1H, s); 7.85-7.82(1H, d); 7.44-7.22(2H, t); 6.88(1H, d); $4.53(1 \mathrm{H}, \mathrm{s}) ; 3.76(2 \mathrm{H}, \mathrm{s}) ; 3.28(2 \mathrm{H}, \mathrm{s}) ; 2.48(3 \mathrm{H}, \mathrm{s})$; IR (KBr, cm-1): 3149, 2945, 1641, 1585, 1510, 1342, 1246, 1139, 1020, 950, 810, 704; MS m/z: $401\left(\mathrm{MH}^{+}\right)$.

\section{RESULTS AND DISCUSSION}

\section{Biological Activity}

The in vitro antifungal activity of compounds C- $1, \mathrm{C}-2$, C-3, C- 4 and C-5 were tested using the standard cup plate agar diffusion method ${ }^{[26]}$ against Aspergillus niger and fumigatus. These fungus species display the highest risk of invasive infections in the recipients of liver and lung transplant. ${ }^{[25]}$ The concentration of test compounds used in the study was 5\% using DMSO as a solvent. Ornidazole was tested as a standard drug for the fungi. The results of the antifungal activity are shown in Table 1. Figs. 5 and 6.

The minimum inhibitory concentration (MIC) required for antifungal activity has been detailed in Table 2 .

A series of ornidazole thiosemicarbazone analogues were synthesized on the basis of literature review on 2-Methyl-5-nitroimidazoles and thiosemicarbazones. The synthesized compounds were elucidated by ${ }^{1} \mathrm{H}$ NMR and IR aspectra.

All the ornidazole analogs were subjected to antifungal evaluation by cup and plate method, and they showed good antifungal activity against Fumigatus and Niger except compound C-4. Unsubstituted amine analog C-2 has shown highest percentage inhibition (96.6\%, $500 \mu \mathrm{g} / \mathrm{mL}$ )against Fumigatus while aromatic amine with or without electronegative atom; analogs C-3 and C-5 have shown highest activity against Niger which is two times than standard drug ornidazole $(100 \%, 1000$ 
Table 1: Zone of inhibition, mean ad standard deviation on the data of antifungal activity of synthesized compounds:

\begin{tabular}{|c|c|c|c|c|c|c|c|c|c|c|c|}
\hline \multirow[b]{2}{*}{ S. No } & \multirow[b]{2}{*}{ Compound } & \multicolumn{6}{|c|}{ Zone of inhibition ( $\mathrm{mm}$ ) } & \multicolumn{2}{|l|}{ Mean } & \multicolumn{2}{|l|}{$S D$} \\
\hline & & \multicolumn{3}{|c|}{ A. fumigatus } & \multicolumn{3}{|c|}{ A. niger } & A. fumigatus & A. niger & A. fumigatus & A. niger \\
\hline 1 & $\mathrm{C}-1$ & 28 & 28 & 27 & 25 & 26 & 26 & 27.67 & 25.67 & 0.58 & 0.58 \\
\hline 2 & $\mathrm{C}-2$ & 28 & 29 & 29 & 26 & 25 & 25 & 28.67 & 25.33 & 0.58 & 0.58 \\
\hline 3 & $\mathrm{C}-3$ & 24 & 23 & 24 & 27 & 28 & 27 & 23.67 & 27.33 & 0.58 & 0.58 \\
\hline 4 & $C-4$ & 10 & 10 & 9 & 13 & 15 & 14 & 9.67 & 14.00 & 0.58 & 1.00 \\
\hline 5 & $C-5$ & 26 & 27 & 26 & 27 & 28 & 26 & 26.33 & 27.00 & 0.58 & 1.00 \\
\hline 6 & DMSO (control) & 0 & 0 & 0 & 0 & 0 & 0 & 0.00 & 0.00 & 0.00 & 0.00 \\
\hline 7 & Ornidazole (10\%) (std.) & 30 & 30 & 30 & 29 & 29 & 29 & 30.00 & 29.00 & 0.00 & 0.00 \\
\hline
\end{tabular}

Table 2: Minimum inhibitory concentration of ornidazole derivatives; MIC $(\mu \mathrm{g} / \mathrm{mL})$

\begin{tabular}{llll}
\hline & & \multicolumn{2}{l}{$M I C(\mu \mathrm{g} / \mathrm{mL})$} \\
\cline { 3 - 4 } S. No & Compound & Aspergillus fumigatus & Aspergillus niger \\
\hline 1 & C-1 & 100 & 200 \\
2 & C-2 & 50 & 100 \\
3 & C-3 & 500 & 50 \\
4 & C-4 & 1000 & $>1000$ \\
5 & C-5 & 200 & 100 \\
6 & DMSO (control) & 0 & 0 \\
7 & Ornidazole & 500 & 200 \\
& (10\%) (std.) & & \\
\hline
\end{tabular}

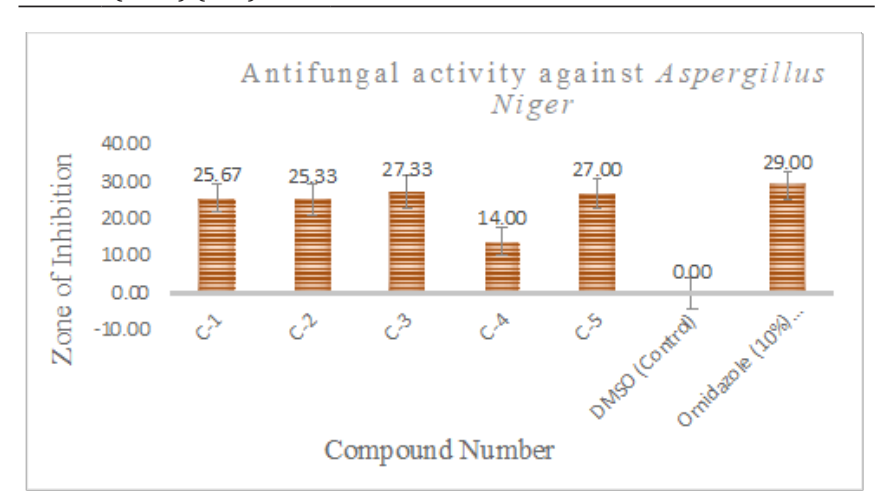

Fig. 5: Antifungal activities of synthesized compounds against Aspergillus fumigatus using ornidazole as standard and DMSO as control

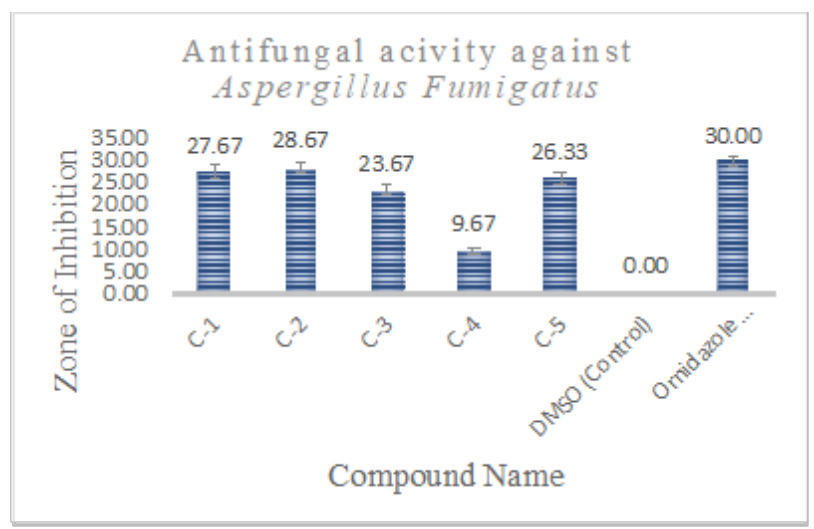

Fig. 6: Antifungal activity of synthesized compounds against Aspergillus niger

$\mu \mathrm{g} / \mathrm{mL}$ ). Thus, the synthesis of a number of ornidazole thiosemicarbazone analogs has been reported in this study. Substituted anilines on reaction with carbon disulfide in aqueous sodium hydroxide solution and dimethyl sulfate afforded methyl aryl carbamodithioate, which on reacting with hydrazine hydrate yielded 4-aryl thiosemicarbazide. Condensation of different thiosemicarbazides with keto group of oxidized ornidazole in acidic medium afforded ornidazole thiosemicarbazone analogs.

The compounds were characterized by melting points, $\mathrm{R}_{\mathrm{f}}$ values, FTIR, and ${ }^{1} \mathrm{H}$ NMR. IR and ${ }^{1} \mathrm{H}$ NMR spectral data confirmed the identity of all the compounds. All the compounds were checked for their antifungal activity using ornidazole as the standard drug. All the compounds exhibited good result against a test organism.

\section{ACKNOWLEDGMNT}

Authors are grateful to Dr. Monica Gulati, Sr. Dean, School of Pharmaceutical Sciences, Lovely Professional University, for providing the research facilities in the department.

\section{REFERENCES}

1. Nigro MM, Palermo AM, Mudry MD, Carballo MA. Cytogenic Evaluation of Nitroimidazole Derivatives. Toxicol In Vitro. 2003; 17:35-40.

2. Elderfield RC. Heterocyclic Compounds (five-membered Hetrocycles Containing Two Hetro Atoms). John Wiley\& Sons New York, Inc: 1961.

3. Olender D, Zwawiak J, Lukianchuk V. Synthesis of Some $N$-Substituted Nitroimidazole Derivatives as Potential Antioxidant and Antifungal Agents. Eur J Med Chem. 2009;44:645-652.

4. Mittal A. Synthetic Nitroimidazoles: Biological Activities and Mutagenicity Relationship. Scientia Pharma. 2009; 77: 497-520.

5. Skold M, Gnarpe H, Hillestrom L. Ornidazole: A New Antiprotozoal Compound for Treatment of Trichomonas Vaginalis Infection. Brit J Vener Dis. 1977; 53: 44-48.

6. Yeung CH, Oberlander G, Cooper TG. Effect of the Male Antifertility Agent Ornidazole on Sperm Function In-Vitro and in the Female Gentinal Tract. J reprod fertil. 1995;103:257-264.

7. Tan SZ, Niu CG, Jiang JH. Optochemical Sensor for an Ornidazole assay Using 1-Amino-4-allyloxyanthraquinone as a Fluorescent indicator. Anal Sci. 2005;21:967-971.

8. Huang J, Cao G, Hu X. Chiral Sepration of rac-Ornidazole and Detection of the Impurity of $(R)$-Ornidazole in $(S)$-Ornidazole Injection and Raw Material. Chirality. 2006;18:587-581.

9. Rossignol JF. Cryptosporidium and Giardia: Treatment Options and Prospects for New Drugs. Exp. Parasitol. 2010; 124: 45-53.

10. Ozkan SA, Senturk Z, Biryol. Determination of Ornidazole in Pharmaceutical Dosage forms Based on Reduction at an Activated Glassy Carbon Electrode. Int J Pharm. 1997;157:137-144.

11. Sobrinho M, Felts dLR. Development of New Dissolution Test and HPLC-RP Method for Antiparasitic Ornidazole Coated Tablets. Quím Nova. 2010;XY:1-4.

12. Abid M, Agarwal SM, Azam A. Synthesis and Antiamoebic Activity of Metronidazole Thiosemicarbazone Analogues. Eur J Med Chem. 2008;43:2035-2039. 
13. Karatas F, Koca H, Servi S. Synthesis and Oxidant Properties of Novel(5-bromobenzofuran-2-yl)(3-methyl-3-mesitylcyclobutyl) Ketonethiosemicarba-zone. Eur J Med. 2006;4:664-669.

14. Benns BG, Gingras BA, Bayley CH. Antifungal Activity of Some Thiosemicarbazones and Their Copper Complexes. Appl Microbiol. 1960;8:353-356.

15. Pinganew R, Prachayasittikul, Rawat R. Synthesis, Cytotoxic and Antimalarial Activities of Benzoyl Thiosemicarbazones Analogus of Isoquinoline and Related Compounds. Molecules. 2010;15:988-996.

16. Zanil F, Mazza P, Benvenuti S, Malmusi L. Synthesis, Characterization, Crystallographic Analysis, Antifungal and Genotoxic Properties of Some 1-methyl-lH-Imidazoles. Eur J Med Chem. 1995;30:729-740.

17. Durel P, Roiron V, Siboulet A. Systemic Treatment of Human Trichomniasis with a Derivative of Nitroimidazole. Brit J Vener Dis. 1960;36(21):21-26.

18. Hoffer M, Grunberg. Synthesis and Antiprotozoal Activity of 1-( 3-Chloro-2-hydroxypropyl)-Substituted Nitroimidazoles. J Med Chem. 1974;17(6):1019.

19. Demirayak S, Kiraz N. Synthesis and antibacterial activities of some 1-[2-(substituted pyrrol-1-yl)ethyl]-2-methyl-5-nitroimidazole derivative. Eur J Med Chem. 1999;34:275-278.

20. Benkli K, Karaburin CA. Synthesis and Antimicrobial Activities of Some New Nitroimidazole Derivatives. Arch Pharm Res. 2003;26(10):773-777.

21. Frank PV, Kalluraya. Synthesis of 1, 3, 4-Oxadiazoles Carrying Imidazole Moiety. Ind J Chem. 2005;44B:1456-1459.

22. Frank V P, Girish KS. Solvent-free Microwave-Assisted Synthesis of Oxadiazoles Containing Imidazole Moiety. J Chem Sci. 2007; 119(1):41-46.

23. Varshney V, Mishera NN. Synthesis of Nitroimidazole Derived Oxazolidinones as Antibacterial Agents. Eur J Med Chem. 2010; 45:661-666.

24. Munksgaard B. Fungal Infections. American Journal of Transplantation. 2004;4(10):110-134.

25. Kumar L, Sarswat A, Lal N. Imidazole Derivatives as Possible Microbicides with Dual Protection. Eur J Med Chem. 2010; 45:817824.

26. Ghodasara TJ, Jivani NP. Antibacterial activity and phytochemical study of ethanolic extract of Triumfetta rhomboidea Jacq. Int J Pharm Sci Drug Res. 2010; 2(1): 40-42.

HOW TO CITE THIS ARTICLE: Kumar N, Aggarwal T, Singh G, Kumar P, Kumar R, Kaur C. Synthesis and Biological Evaluation of Thiosemicarbazone Analogues of Ornidazole as Antifungal Agents. Int. J. Pharm. Sci. Drug Res. 2020; 12(1): 73-79. DOI: 10.25004/IJPSDR.2020.120112 